JOURNAL OF SECURITY AND SUSTAINABILITY ISSUES

ISSN 2029-7017 print/ISSN 2029-7025 online

2019 September Volume 9 Number 1

http://doi.org/10.9770/jssi.2019.9.1(11)

\title{
Scopus
}

\section{INTRODUCTION OF CREATIVE ECONOMY IN INTERNATIONAL RELATIONS: ASPECTS OF DEVELOPMENT SECURITY}

\author{
Iryna Perevozova ${ }^{1}$, Nadiia Shmygol ${ }^{2}$, Dina Tereshchenko ${ }^{3}$, Kateryna Kandahura ${ }^{4}$, Olga Katerna ${ }^{5}$ \\ ${ }^{1}$ Ivano-Frankivsk National Technical University of Oil and Gas, 15 Karpatska Street, Ivano-Frankivsk, Ukraine \\ ${ }^{2}$ Zaporizhzhya National University, 66 Zhukovskogo Street, Zaporizhzhya, 69600, Ukraine \\ ${ }^{3 *}$ Kharkiv National University of Civil Engineering and Architecture, Sumska street, 40, Kharkiv, Ukraine; \\ ${ }^{4}$ Kyiv National University of Trade and Economics, Kyiv, 19 Kyoto St., 01100, Ukraine \\ ${ }^{5}$ National Aviation University, 1 Kosmonavta Komarova Ave., Kyiv, 03058, Ukraine \\ E-mail: ${ }^{3 *}$ koaduep@gmail.com
}

Received 14 December 2018; accepted 15 June 2019; published 30 September 2019

\begin{abstract}
The scientific article outlines the main aspects of deploying a creative economy and shaping its impact on the security of world countries' development, especially in the context of national innovation policy. The current power balance in the world regarding the development of a creative economy, the dynamic modeling and analysis of various aspects of the creative economy have been determined in the article. A Summary of indicators and factors for assessing the level of achievements of the creative economy and its relation to the security of individual countries has been carried out.
\end{abstract}

Keywords: development security; creative economy; innovation policy; education level; human capital asset; infrastructure; multiculturalism; Cultural and creative markets

Reference to this paper should be made as follows: Perevozova, I.; Shmygol, N.; Tereshchenko, D.; Kandahura, K.; Katerna, O. 2019. Introduction of creative economy in international relations: aspects of development security, Journal of Security and Sustainability Issues 9(1): 139-154. http://doi.org/10.9770/jssi.2019.9.1(11)

JEL Classifications: A13; F 29

\section{Introduction}

Economic transformations of the beginning of the $21^{\text {st }}$ century will be manifested in the development of a post-industrial economic mode of production. This process, of course, is quite lengthy and controversial. However, now it is possible to distinguish a number of its characteristic features, such as the integral nature of the economic system, which creates the conditions for joining private initiative and innovation activity, and the multi-layered economy. This determines the socio-economic efficiency of reproduction, the pace of economic growth and requires resource support.

\section{Literature Survey}

The problem of creativity is becoming very urgent under these fundamentally new socio-economic conditions, - the individual's ability to create new concepts, the formation of new ideas and ways of their implementation in the economy. The work of such authors is well known in the scientific circles (Benešová, Hušek, 2019; Drobyazko S., 2019; Florida, 2002; Howkins, 2001; Ryan, 2003; Scott, 2003; Tepper, 2002; Tkachenko, 2019). Their scientific achievements and topical issues of creativity as an innovation resource of economic development and form the value of this study. 
The purpose of the study is to develop recommendations for the sustainable development of a creative national economy in the light of international trends.

\section{Methods}

With a view to determine how and which countries in the world are ready to transit to a knowledge-based economy, and therefore have a sufficiently developed creative economy, we will use one out of several available methodologies for determining the level of willingness of countries for transition to a knowledge-based economy (Kisel'áková et al., 2018; Korauš et al., 2018; Baltgailis, 2019; Prakash, Garg, 2019). This analysis will make it possible to identify the economics most adapted to the new stage.

\section{Results}

The first element of the knowledge-based economy to be considered is the education index (Table 1). The Education Index is a composite index of the United Nations Development Program (UNDP). It is one of the key indices of social development. It is used to calculate the Human Development Index in the United Nations Special Report on Human Development (An Interview with John Howkins).

Table 1. Index of education in the countries of the world as of 2017

\begin{tabular}{|c|c|c|}
\hline Country & Position in the index of human development & Education Index (0-1) \\
\hline Australia & 2 & 0.939 \\
\hline Denmark & 5 & 0.923 \\
\hline New Zealand & 13 & 0.917 \\
\hline Norway & 1 & 0.916 \\
\hline Germany & 4 & 0.910 \\
\hline Ireland & 8 & 0.906 \\
\hline Iceland & 9 & 0.900 \\
\hline USA & 10 & 0.897 \\
\hline The Netherlands & 7 & 0.896 \\
\hline Great Britain & 16 & \\
\hline
\end{tabular}

Source: UNCTAD Creative Economy Outlook and Country Profile report, 2018

The index measures the achievements of the country in terms of the level of education of its population in two main indices:

1. The education index of an adult population ( $2 / 3$ of weight).

2. Index of aggregate share of disciples in primary, secondary and higher education (1/3 of weight).

The two measured levels of education are reduced to the Final Index, which is standardized in the form of numerical values from 0 (minimum) to 1 (maximum). It is considered that developed countries should have a minimum of 0.8 , although many of them have a score of 0.9 or higher. One can see that the human development index is influenced by many factors besides education. Therefore, a high level of education does not yet mean a high level of human development in the country (UNCTAD Creative Economy Outlook and Country Profile report, 2018).

Regarding Australia, education has been steadily increasing from 1990 to 2013. In 2013, index having reached the point - 0.939, stopped developing and continues to remain at this level. Denmark has experienced very rapid growth since 1990 (0.690) by 2013 (0.934), followed by a decline in 2014 to the index -0.923 , which is held up to the present. Regarding New Zealand, the index continued to increase indefinitely until 2014, as was the case in Germany, Iceland and Ukraine. Regarding the Netherlands, growth was up to 2013. As for the country that ranked first in the index of human development - Norway, the level of education grew every year, except for 
2011, when there was a slight decline, but the following year they made a fairly large leap forward. The UK had the same dynamics - growth, a sharp decline in 2011 and a rebound to 2014. Regarding Ireland, the situation is similar to Norway, but instead of a big jump, they had a large decline in 2011 (from 0.907 to 0.862). After this, Ireland took baby steps to reach its past level. Regarding the United States, there was a slight decline from 1995 to 2000 , but in 2005 they surpassed the level of 1995. After this there was an increase, except for stagnation in 2011-2012 and 2014-2017. The second element to be considered is an innovative system (Table 2).

Table 2. Global Innovation Index 2017

\begin{tabular}{|c|c|c|c|c|c|}
\hline \multirow{2}{*}{ Country } & \multirow{2}{*}{ Score $(0-100)$} & \multicolumn{2}{|c|}{ Ranking } & \multirow{2}{*}{ Efficiency factor (0-1) } & \multirow{2}{*}{ Ranking } \\
\hline & & 2017 & 2016 & & \\
\hline Switzerland & 67.69 & 1 & 1 & 0.95 & 2 \\
\hline Sweden & 63.82 & 2 & 2 & 0.83 & 12 \\
\hline The Netherlands & 63.36 & 3 & 9 & 0.93 & 4 \\
\hline USA & 61.40 & 4 & 4 & 0.78 & 21 \\
\hline Great Britain & 60.89 & 5 & 3 & 0.78 & 20 \\
\hline Denmark & 58.70 & 6 & 8 & 0.71 & 34 \\
\hline Singapore & 58.69 & 7 & 6 & 0.62 & 63 \\
\hline Finland & 58.49 & 8 & 5 & 0.70 & 37 \\
\hline Germany & 58.39 & 9 & 10 & 0.84 & 7 \\
\hline Ireland & 58.13 & 10 & 7 & 0.85 & 6 \\
\hline
\end{tabular}

Source: The Global Innovation Index 2017

The Global Innovation Index is a global study and its global ranking in terms of innovation. It is based on the methodology of the International Business School INSEAD, France (Tvaronavičienè, M., 2018). To understand why countries are becoming leaders in innovation, let's consider the different countries of the region that have succeeded in this area and consider the strong points that have led them to become regional innovation leaders (Table 3 ).

Table 3. Regional Leaders in the sphere of innovations

\begin{tabular}{|c|c|c|}
\hline Region/rating & Country & Place in the global ranking GII-2017 \\
\hline \multicolumn{3}{|l|}{ North America } \\
\hline 1 & USA & 4 \\
\hline 2 & Canada & 18 \\
\hline \multicolumn{3}{|c|}{ The Sub-Saharan countries of Africa } \\
\hline 1 & South Africa & 57 \\
\hline 2 & Mauritius & 64 \\
\hline 3 & Kenya & 80 \\
\hline \multicolumn{3}{|c|}{ Latin America and the Caribbean } \\
\hline 1 & Chile & 46 \\
\hline 2 & Costa-Rica & 53 \\
\hline 3 & Mexico & 58 \\
\hline \multicolumn{3}{|l|}{ Central and South Asia } \\
\hline 1 & India & 60 \\
\hline 2 & Iran, Islamic Republic & 75 \\
\hline 3 & Kazakhstan & 78 \\
\hline \multicolumn{3}{|l|}{ North Africa and West Asia } \\
\hline 1 & Israel & 17 \\
\hline 2 & Ciprus & 30 \\
\hline
\end{tabular}




\begin{tabular}{|c|c|c|}
\hline \multicolumn{1}{|c|}{ United Arab Emirates } & 35 \\
\hline Southeast Asia, East Asia and Oceania & Singapore & 11 \\
\hline 1 & Republic of Korea & 14 \\
\hline 2 & Japan & 1 \\
\hline Europe & & \\
\hline & Switzerland & 2 \\
\hline
\end{tabular}

Source: OECD Science, Technology and Industry Scoreboard 2018

The Global Innovation Index is made up of 82 different variables, which detail the innovative development of countries around the world, being at different levels of economic development. The authors of the study believe that the success of the economy is accounted for by both the availability of innovative potential and the conditions for its implementation. Therefore, the Index is calculated as a weighted total of estimates for the two groups of indices (World Intellectual Property Organization. Statistical Country Profiles):

1. Available resources and conditions for innovation (Innovation Input):

- institutes;

- human capital asset and research;

- infrastructure;

- development of the domestic market;

- business development.

2. Achieved practical results of innovation (Innovation Output):

- development of technologies and knowledge-based conomy;

- creative activity results.

Thus, the Final index is a ratio of costs and effect, which allows to objectively assess the effeciency of efforts aimed at developing innovation in one or another country.

With regard for 2017, Switzerland leads the overall ranking for the seventh consecutive year, with twenty-four of the first twenty-five places belonging to high-income countries - China, which ranked twenty-second, is an exception. China has become the first middle-income country since 2016 to rank among the leading twenty-five countries in the innovation ranking.

Indices of a group of middle and low income countries significantly exceed those parameters that could be said based on their level of development: within the current year, the group of "dynamic innovators" includes a total of 17 countries, which is slightly more than in 2016. Nine of them, including Kenya and Rwanda, are located in the sub-Saharan Africa and three in Eastern Europe.

A group of Asian states, including Indonesia, Malaysia, Singapore, Thailand, the Philippines and Vietnam, who are actively improving their innovative ecosystems and pursuing high-quality results for a number of important indices, are approaching such innovative giants as China, Japan and the Republic of Korea. In particular, it concerns the development of education, $R \& D$, the growth rate of labor productivity and the export of high-tech products.

Looking at such an element of the knowledge-based economy as innovation systems - we see that European countries are also in a higher position, which once again emphasizes their desire and willingness to achieve a new economy (Korauš, et al., 2019). Likewise, with respect to this share of the knowledge economy, Asian countries are gaining momentum, among them - China, Japan, Singapore. This gives them a push forward to a knowledge-based economy. 
The third element of the knowledge-based economy to be considered is the state of information and communication technologies (ICT). The ICT Development Index (IDI) is a composite index that characterizes the achievements of the countries of the world in terms of information and communication technologies development. It is calculated according to the methodology of the International Telecommunication Union (International Telecommunication Union), a specialized unit of the UN, which defines world standards in the field of ICT.

The index was developed in 2007 on the basis of 11 indices that the International Telecommunication Union (ITU) operates in its ICT development assessments. The index reduces these indices to a single criterion meant to compare the achievements of the world in the development of ICT and can be used as a tool for benchmarking at the global, regional and national levels. These indices relate to access to ICT, the use of ICT, as well as skills, that is, the practical knowledge of these technologies by the population of countries covered by research. The authors of the study emphasize that the level of ICT development today is one of the most important indices of the economic and social well-being of the state (Center for an Urban Future, 2005).

Recent (ITU) data regarding developments in ICT show that progress is still being made on the ability to establish connections and use ICTs. Mobile networks of mobile communications are increasingly spreading, which now occupy a leading position in the provision of basic telecommunication services. Broadband communication services are growing steadily. Still there are significant digital divides between countries and regions, as well as between developed and developing countries, especially LDC. These devides are evident when using the Internet, as well as in the ability to establish connections. There exists a significant digital gender gap.

With regard for 2017, IDI covers 176 countries of the world. Comparison made with the IDI of 2016 shows that progress in access to and use of ICTs remains in almost all countries (Table 4).

Table 4. Ratings and IDI values, 2017 and 2016

\begin{tabular}{|c|c|c|c|c|}
\hline Country & Position - 2017. & IDI - 2017. & Position 2016. & IDI - 2016. \\
\hline Iceland & 1 & 8.98 & 2 & 8.78 \\
\hline Republic of Korea & 2 & 8.85 & 1 & 8.80 \\
\hline Switzerland & 3 & 8.74 & 4 & 8.68 \\
\hline Denmark & 4 & 8.71 & 3 & 8.53 \\
\hline Great Britain & 5 & 8.65 & 5 & 8.47 \\
\hline Honkong, China & 6 & 8.61 & 6 & 8.40 \\
\hline The Netherlands & 7 & 8.49 & 7 & 8.45 \\
\hline Norway & 8 & 8.47 & 9 & 8.40 \\
\hline Luxemburg & 9 & 8.47 & & 8.32 \\
\hline Japan & 10 & 8.43 & & \\
\hline
\end{tabular}

Source: Measuring the Information Society Report 2017

Iceland occupies the first place in IDI's ranking in 2017 - an IDI value of 8.98. It is followed by six European countries and three countries in the Asia-Pacific region, having competitive ICT markets, which maintain high levels of investment and innovation in the field of ICT for many years. The countries that are at the top of the IDI distribution also have high levels of economic well-being, literacy and other skills that enable citizens to fully enjoy the benefits of access to communications.

The average IDI rose by 0.18 points in all countries from 2016 to 2017, reaching 5.11 points, the first time rising above the middle of the scale. Regarding IDI of 2016, improvements are particularly significant among middleincome countries, many of which are middle-income developing countries, although the position change in the rating was only limited. The most significant improvements in IDI values are observed in Namibia, the Islamic Republic of Iran and Gabon - all of these values have grown by 0.50 points or more (Table 5). 
Table 5. The most dynamic countries in IDI rankings and values, 2016-2017

\begin{tabular}{|c|c|c|c|c|c|}
\hline \multicolumn{3}{|c|}{ Changes in IDI rating } & \multicolumn{3}{c|}{ Changes in IDI values } \\
\hline $\begin{array}{c}\text { IDI position } \\
\text { in } 2017\end{array}$ & Country & $\begin{array}{c}\text { Changes in } \\
\text { IDI position }\end{array}$ & $\begin{array}{c}\text { IDI position } \\
\text { in 2017 }\end{array}$ & $\begin{array}{c}\text { Changes in } \\
\text { IDI values }\end{array}$ \\
\hline 95 & Uzbekistan & 8 & 118 & Namibia & 0.57 \\
\hline 159 & Afghanistan & 6 & 81 & Iran & 0.54 \\
\hline 36 & Croatia & 6 & 114 & Gabun & 0.50 \\
\hline 88 & Suriname & 6 & 139 & Cyprus & 0.47 \\
\hline 152 & Uganda & 6 & 111 & Indonesia & 0.47 \\
\hline 42 & Uruguay & 6 & 112 & Bolivia & 0.47 \\
\hline 139 & Laos & 5 & 122 & Turkey & 0.46 \\
\hline 35 & Latvia & 5 & 67 & China & 0.43 \\
\hline 135 & Myanmar & 5 & 135 & Myanmar & 0.42 \\
\hline 118 & Namibia & 5 & 95 & Uzbekistan & 0.42 \\
\hline 122 & Timor-Leste & 5 & 5 & \\
\hline 67 & Turkey & 5 & & & 0.42 \\
\hline
\end{tabular}

Source: Measuring the Information Society Report 2017

All countries, except for eight, have improved their overall IDI values. Despite the significant increase in the share of Internet users in the country, improvements in the sub-index of ICT use were made due to a significant increase in subscriptions to mobile broadband communicationnetworks, which increased from 35.82 to 66.15 per 100 inhabitants during the year. Namibia also improved its value in the sub-index of access by 0.16 points, from 4.23 to 4.39 , and in the sub-index of ICT skills by 0.11 points, from 3.85 to 3.96 .

In general, as in previous years, the sub-index of use of ICT grew faster by 0.31 points than sub-access points and skills, both of which rose by an average of 0.10 points. The index of contracts for mobile broadband made the most significant contribution to improving the values of IDI, which increased by 12.9 points over the year. Conversely, the fixed-line contract rate continued to decline gradually in most countries.

The problem of reducing the digital divide between countries, connected to a greater or lesser extent, still remains. Regarding IDI in 2017, the gap between the countries with the highest and lowest indices points rose to 8.02 points (from 10.0). As in previous years, there exists a strong relationship between economic development and the development of ICTs, with the least developed countries (LDCs) occupying 37 out of 44 places in the lower (connected to the smallest extent) quarter of distribution. The average IDI in the LDC increased by 0.15 points in the year and by 0.22 points in other developing countries, suggesting that the LDC backlog in ICT development may increase further.

As IDI shows, there are significant differences between the geographical regions in the levels of ICT development (Fig. 1). There are also significant fluctuations in the experience of individual countries within each region. IDI differences between regions and individual countries are mainly related to levels of economic development.

Europe remains the leading region in the development of ICTs. There is the highest average IDI among the regions of the world (7.50 points). This reflects the high levels of regional economic development, the availability of competitive communication markets and high levels of ICT skills. Regarding all countries in the region of Europe, the IDI value is higher than the average world. Only 28 out of 40 countries are in the highest quarter, and only one - Albania, is not part of the upper half of the division. The most noticeable increase in values is observed in Cyprus and Turkey.

With regard for the region of North and South America, the IDI rating is headed by the United States and Canada. Most countries in the region are two medium-sized quartile groups, and only two least-connected counties 
(LCCs) - Cuba and Haiti - are located in the lower quartile group. The most significant improvements in this region are observed in countries with averages in South and Central America and the Caribbean.

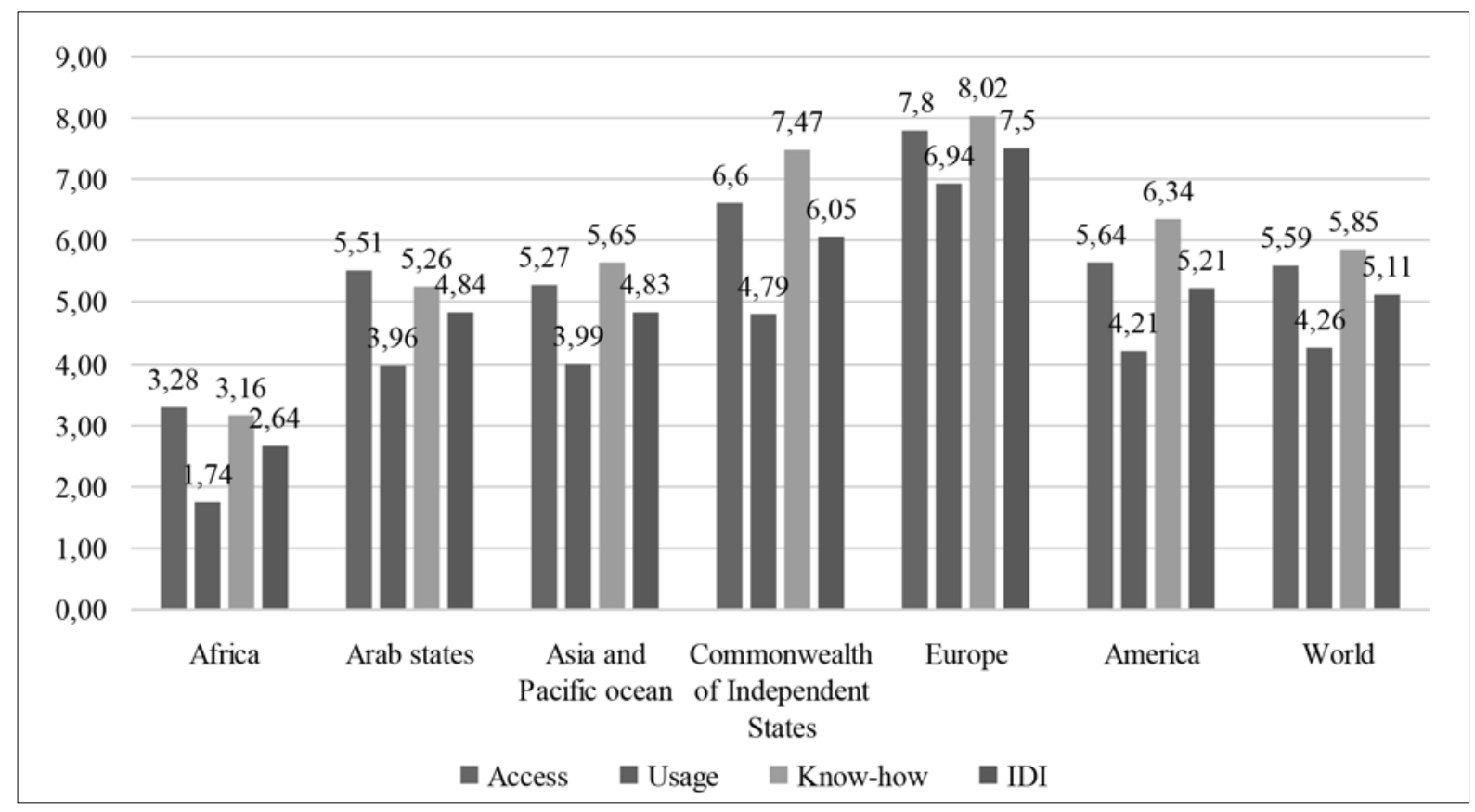

Fig. 1. Average IDI and sub-indices, world and regions, 2017

Source: Developed by the authors according to the source (Measuring the Information Society Report 2017)

On the contrary, the Asia-Pacific region is most heterogeneous as regards the development of ICT. Seven countries in the region, that have IDI higher than 7.50 points, belong to the upper quartile of the global IDI of 2017, including the Republic of Korea, which ranks second.

The region of the Arab states is also extremely diverse in terms of IDI. This region has a number of high-income oil producing countries, three of which belong to the upper IDI quartile, as well as a number of low-income countries, four of which are LCC. The most notable improvements in this region are observed in middleincome countries, whose average figures have grown by magnitudes, twice higher than those in the upper and lower regions of the regional distribution.

Africa remains a region with the lowest IDI indices. Regarding 2017, the average IDI value for this region is 2.64 points, which is more than half of the average world value - 5.11. Only one country of the region Mavrikiy - is located near the upper half of the global IDI division, which is 28 countries among 38 , included in the bottom quartile (LCC) in 2017. This is a generally low area of economic development in the region.

The last element is the institutional regime for knowledge-based economics. It is estimated as standardized number of online government sites. Index of Electronic E-Government development (The UN Global E-Government Development Index) of United Nations organization (UNO) - is a comprehensive index, which assesses willingness and capabilities of the national state structures as regards using information and communication technologies (ICT) aimed at rendering public services to citizens (Hall, 1998). Ii is ssued every two years.

The research contains data on the level of e-government development in different countries, as well as a systematic assessment of trends in the use of ICT by government agencies. All countries covered by this research are ranked in a rating based on a weighted index of estimates for three main components:

1) the degree of coverage and quality of Internet services;

2) the level of development of the ICT infrastructure;

3) human capital asset. 
The number of countries that use e-government to provide public services online through the use of universal platforms has sharply increased. With regard for 2003, only 45 countries had a universal platform, and only 33 countries provided an opportunity for online transactions. According to 2016 poll, 90 countries offer one or more individual portals either for government information, or for online services, or both, and 148 countries provide at least one platform for online transaction services (Makedon, V.; Drobyazko, S.; Shevtsova, H.; Maslosh, O.; Kasatkina, M., 2019).

More and more countries are trying to ensure the public institutions to be more open, efficient, accountable and transparent with the help of e-government. Many governments around the world open up their data to inform the public and to be under control. The index as per 2016 shows that 128 countries provide data on public expenditures in electronic formats (United Nations e-government survey, 2017).

Owing to easy access to social networks, more and more countries are moving towards joint decision-making. Although developed countries, especially European ones, are among the top 50 in this sphere, many developing countries, especially low and middle income countries, also succeed (Table 6). Extending e-participation can support the Goals of Sustainable Development (GSD) by expanding the number of participants in decisionmaking

Table 6. Index of e-government development (EGDI), 2016

\begin{tabular}{|c|l|c|c|c|c|}
\hline \multirow{2}{*}{ Position } & \multicolumn{1}{|c|}{ Country } & $\begin{array}{c}\text { Online } \\
\text { Services Index (OSI) }\end{array}$ & Human Capital Index (HCI) & $\begin{array}{c}\text { Telecommunications } \\
\text { Infrastructure Index (TI) }\end{array}$ & EGDI \\
\hline 1 & Great Britain & 1.0000 & 0.9402 & 0.8177 & 0.9193 \\
\hline 2 & Australia & 0.9783 & 1.0000 & 0.7646 & 0.9143 \\
\hline 3 & Korea & 0.9420 & 0.8795 & 0.8530 & 0.8915 \\
\hline 4 & Singapore & 0.9710 & 0.8360 & 0.8414 & 0.8828 \\
\hline 5 & Finland & 0.9420 & 0.9440 & 0.7590 & 0.8817 \\
\hline 6 & Sweden & 0.8768 & 0.9210 & 0.8134 & 0.8704 \\
\hline 7 & The Netherlands & 0.9275 & 0.9183 & 0.7517 & 0.8659 \\
\hline 8 & New Zealand & 0.9420 & 0.9402 & 0.8247 & 0.8653 \\
\hline 9 & Denmark & 0.7754 & 0.9530 & 0.7502 & 0.8510 \\
\hline 10 & France & 0.9420 & 0.8445 & 0.3968 & 0.8456 \\
\hline 62 & Ukraine & 0.5870 & 0.8390 & & 0.6076 \\
\hline
\end{tabular}

Source: Developed by the authors according to the source (United nations e-government survey, 2017)

Countries continue to advance to higher levels of e-government. With regard for 2016, the number of countries with very high and high rates of e-government development (EGDI) has increased.

Still, there are gaps between regions; $66 \%$ of the 29 countries with very high levels of EGDI are European, while African countries account for $81.2 \%$ of the low level of EGDI. Africa (average EGDI 0.2882) and Oceania (average EGDI 0.4154) are below the global mean of EGDI. Asia index equals 0.5132, American one equals 0.5245 , and Europian one is 0.7241 (Table 7).

Table 7. Average values of EGDI and sub-indices in regions, 2016

\begin{tabular}{|l|c|c|c|c|c|c|}
\hline \multicolumn{1}{|c|}{ Region } & Africa & America & Asia & Europe & Pacific Islands & World \\
\hline EGDI & 0.2882 & 0.5245 & 0.5132 & 0.7241 & 0.4154 & 0.4922 \\
\hline OSI & 0.2567 & 0.4959 & 0.512 & 0.6926 & 0.2966 & 0.4623 \\
\hline TII & 0.1724 & 0.3844 & 0.373 & 0.6438 & 0.2599 & 0.3711 \\
\hline HCI & 0.4355 & 0.6933 & 0.6545 & 0.836 & 0.6897 & 0.6433 \\
\hline
\end{tabular}

Source: Knowledge Assessment Methodology, 2018 
With regard for LDC, the development deficit as regards the e-government reflects the scale of the problems faced by these countries, including in the sphere of sustainable development. It is very important to develop the ICT infrastructure, improve access to knowledge and technology, and build appropriate capacities to achieve the many important goals of sustainable development in these countries. At the same time, some LDC have made progress in e-government.

Small Island Developing States (SIDS) should benefit greatly from e-government, but their EGDI remains slightly below the global mean value. Both LDCs and SIDS partnerships, as well as international and regional cooperation, will be crucial to achieving progress in e-government and ICT in general. It can also be noted that the high level of e-governance is positively influenced by progress in some areas of the CSD (Centre of Strategical Developments), in particular, in the areas of competition and fighting against corruption (Dalevska, N., Khobta, V., Kwilinski, A., \& Kravchenko, S., 2019).

After analyzing all elements of the knowledge-based economy, we can distinguish three countries that are included in the top ten in all the considered indices - Denmark, the Netherlands and the United Kingdom. Let's calculate the index of knowledge- based economy for these countries (Table 8). But then, in more detail, we will consider and compare the "country leaders" with the knowledge-based economy and consider the state of the creative economy in these countries.

Table 8. Calculation of the knowledge-based economy index

\begin{tabular}{|c|c|c|c|c|c|}
\hline Country $\quad$ Index & $\begin{array}{l}\text { Education } \\
\text { Level Index }\end{array}$ & $\begin{array}{l}\text { Global Innovation } \\
\text { Index }\end{array}$ & $\begin{array}{l}\text { ICT Development } \\
\text { Index }\end{array}$ & $\begin{array}{c}\text { E-government } \\
\text { Development Index }\end{array}$ & $\begin{array}{c}\text { Knowledge- } \\
\text { based economy } \\
\text { Index }\end{array}$ \\
\hline Denmark & 0.923 & 58.70 & 8.71 & 0.8510 & 0.808 \\
\hline The Netherlands & 0.897 & 63.36 & 8.49 & 0.8659 & 0.811 \\
\hline Great Britain & 0.896 & 60.89 & 8.65 & 0.9193 & 0.822 \\
\hline
\end{tabular}

Source: UNDP. Human Development Report, 2018

Consequently, following this assessment methodology, Denmark, the Netherlands and the United Kingdoms' willingness to transit to the knowledge-based economy sounds the highest among all countries of the world.

The next three indices - human capital asset and research, infrastructure, market degree of development - are held more or less at one level, which is not to say about the latter. Indices of business organization, knowledge and technological outcomes in Denmark and the UK are much lower as compared to the Netherlands. This allowed the Netherlands to step forward in the ranking of innovations (Delery, Roumpi, 2017).

Denmark has the highest growth among the top ten, it is steadily progressing from the tenth place in 2017 and the 8th in 2016. The country is improving its position in almost all elements, except for the market degree of development, where it holds the sixth place, as well as knowledge and technological results ( $16^{\text {th }}$ place $)$, where it lost two positions. At the level of sub-elements, Denmark has grown most in education ( $4^{\text {th }}$ place $)$, ICT $\left(14^{\text {th }}\right)$, environmental sustainability $\left(11^{\text {th }}\right.$ place $)$, innovation $\left(17^{\text {th }}\right)$, knowledge dissemination $\left(17^{\text {th }}\right)$ and intangible assets $\left(25^{\text {th }}\right)$.

Denmark ranks first among many indices, including education, researchers, ICT use and scientific and technical articles. It also refines its position in many areas, such as government expenditure per student, GDP per unit of energy consumption, cooperation in the field of university and industrial research, export of ICT services, etc. (Makedon, et al., 2019).

There exist opportunities for further improvement, in particular in the field of higher education (19), general infrastructure (44), trade, competition and scale of the market (37), influence of knowledge (34). Relatively weak indicators include - graduates in the field of science and technology, the formation of gross capital and 
GDP growth per employee.

The United Kingdom (UK) moved from $3^{\text {rd }}$ to $5^{\text {th }}$ place in 2017. It refines its position in a number of key areas, namely, institutes (9), human capital asset and research (6), and business organization (13). Regarding the "lower" levels in the UK, one can distinguish the political environment ( $18^{\text {th }}$ place $)$, education $\left(22^{\text {nd }}\right.$ place $)$ and knowledge aquisition $\left(28^{\text {th }}\right.$ place). The country loses its position in two elements: knowledge and technological results (13), which fell by four places with the largest drop in the sub-element of knowledge dissemination (38), and creative activity (fourth place).

At the level of sub-elements, some education costs, student spending on state-of-the-art, IP payments, import and export of ICT services, GDP per employee growth rate and national feature films are one of the greatest improvements. On the contrary, positions such as the results of the International Student Assessment Program, the use of ICT and patent families lose most of the positions. The United Kingdom retains its first place in quoted documents and receives $1^{\text {st }}$ place in government online services and e-participation.

The Netherlands took the third position in 2017, taking second place in the sub-index of innovation production and the fourth - in the rate of innovation efficiency. Indeed, the Netherlands lost five positions as a result of large volatility of selected data in 2016, which are now better taken into account. As a result, the Netherlands ranked sixth in net inflow of Foreign Direct Investment (FDI), and the first - in the outflow of FDI in 2017.

The Netherlands has improved its ratings in a number of other areas, including education ( $18^{\text {th }}$ place), innovation links ( $7^{\text {th }}$ place) and knowledge impact $\left(17^{\text {th }}\right.$ place), partly due to R \& D revenues funded abroad and education costs. The weak spheres of the country include: higher education ( $49^{\text {th }}$ place), general infrastructure $\left(30^{\text {th }}\right)$, environmental sustainability $\left(39^{\text {th }}\right.$ place $)$, credit $\left(35^{\text {th }}\right)$ and investment $\left(26^{\text {th }}\right.$ place $)$ (European Parliament resolution of the promotion of European cultural and creative sectors as sources of economic growth and job).

So, as we see, the Netherlands has really achieved much more success and deserved to rank third, ahead of Denmark and Great Britain.

With regard to the development of ICTs, as was already mentioned, Europe is the region with the highest average IDI in 2017. As in previous years, most of the highest ranking positions in the regional rating are occupied by the countries of Northern and Western Europe, including Denmark, the United Kingdom and the Netherlands, which ranked 3, 4 and 5 respectively in the regional rating.

There is no big difference between these countries in sub-indexes. They gain the highest value almost in all parameters, except stationary communication and the Internet. Still, this situation is observed in almost all countries. This is due to the transition of people to cellular communications and mobile Internet. Although the UK has the largest share of the population of these three countries, which uses stationary communication (Figure 2). 


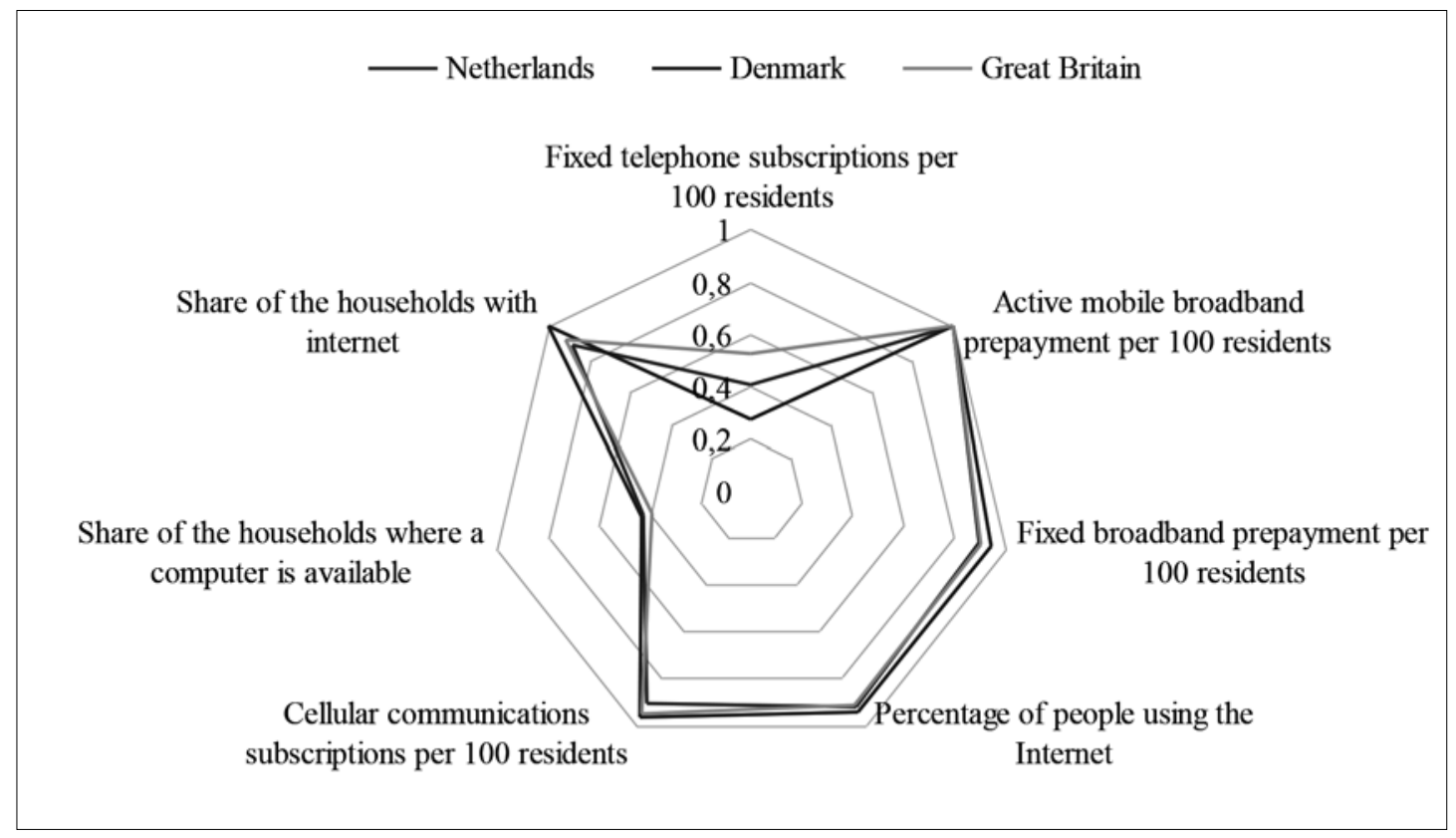

Fig. 2. The value of sub-indexes of the IDI with regard for the Netherlands, Denmark and the United Kingdom, 2017

Source: Developed by the authors according to the source (UNCTAD Creative Economy Outlook and Country Profile report, 2018)

As for the Netherlands, this country was listed in the most dynamic countries by the IDI rating in the European region. Its rating has grown to three positions, from 10th in 2016 to 7 th in 2017.

Regarding the e-government index, e-governments are constantly evolving around the continent of Europe, it can be called the leading region. The countries that we consider are among the top 10 leading ones of this index - Great Britain ( $1^{\text {st }}$ place $)$, the Netherlands ( $7^{\text {th }}$ place $)$, Denmark $\left(9^{\text {th }}\right.$ place) (Figure 3$)$.

Denmark and the United Kingdom are striving for a "digital dictatorship", or so called "digital by default", while the essence of the matter is that the maintenance and development of any physical system is carried out only when a digital alternative is missing. That is, the physical system becomes an alternative, and digital becomes the usual state of the system's operation. The use of digital identity is fast becoming a norm and an integral part of any functional e-government website in these countries.

Figure 3 shows that the UK e-government index is the highest. Due to this, it ranks first in the rating. Regarding the index of Human Capital Index (HCI), the leaders achieved almost identical results. This index consists of four components, namely: adult literacy rate, aggregate total enrollment ratio for primary, secondary and higher education, expected and average years of study. 


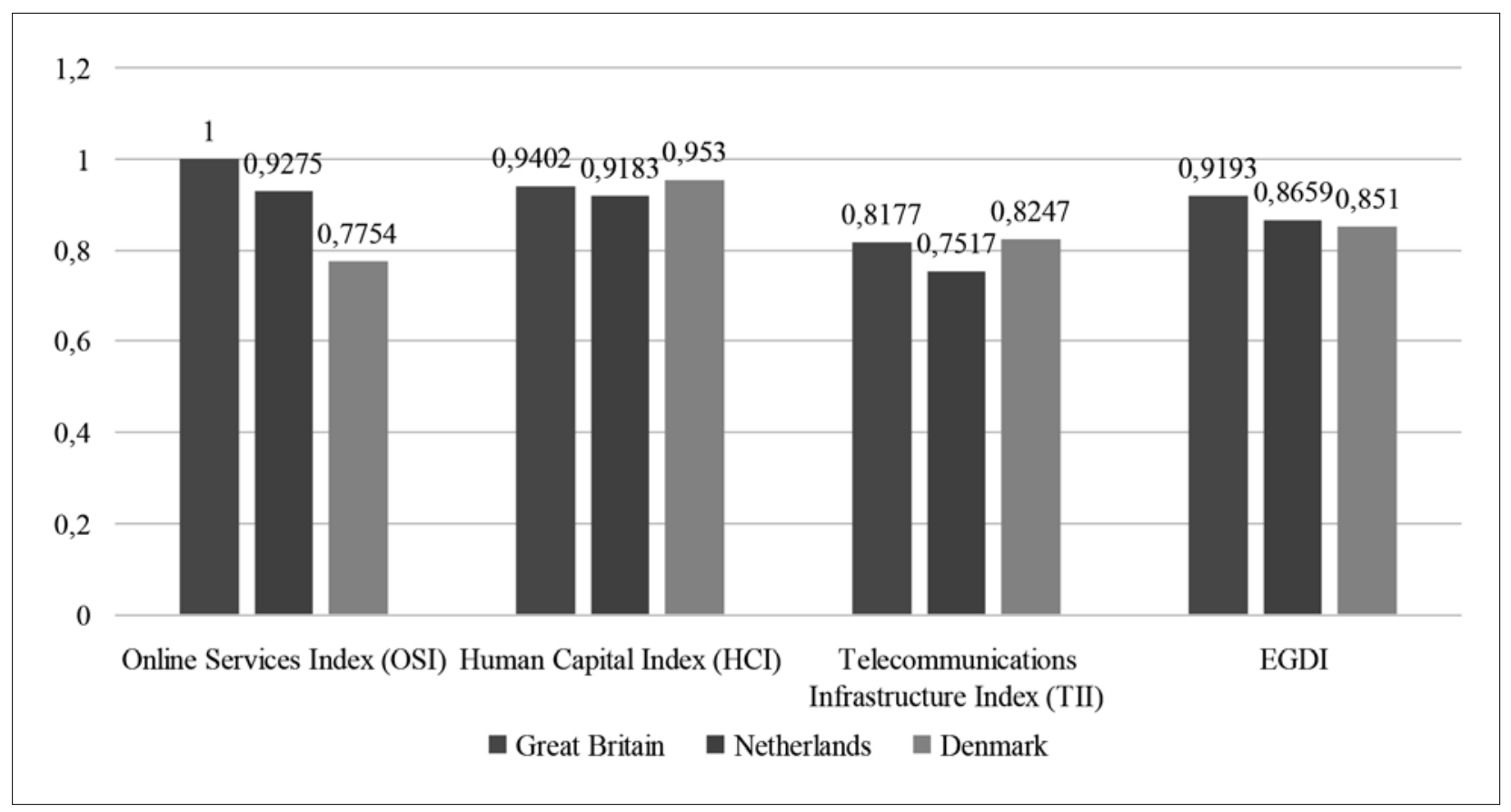

Fig. 3. Comparison of e-government Indices in the UK, the Netherlands and Denmark

Source: Developed by the authors according to the source (UN E-Government Knowledge DataBase)

The Netherlands has fallen behind Denmark and the United Kingdom as regards the Telecommunications Infrastructure Index (TII), which is an arithmetic average of five indices: planned Internet users, number of fixed telephone lines, number of mobile subscribers, the number of wireless broadband subscriptions and the number of fixed subscribers per 100 residents.

Table 9. Cultural and creative markets in the EU-28

\begin{tabular}{|l|c|c|}
\hline \multicolumn{1}{|c|}{ Markets } & Sales, billions of US dollars & Number of employees \\
\hline Advertising & 143.7 & 1,028000 \\
\hline Architecture & 59.0 & 661,000 \\
\hline Books & 52.5 & 973,000 \\
\hline Games & 29.8 & 92,000 \\
\hline Cinema & 24.4 & 704,000 \\
\hline Music & 23.5 & 1289,000 \\
\hline Newspapers & 104.1 & 1183,000 \\
\hline Stage art & 44.0 & 115,000 \\
\hline Radio broadcasting & 14.5 & 746,000 \\
\hline TV broadcasting & 129.2 & 803,000 \\
\hline Decorative art & 121.5 & \\
\hline
\end{tabular}

Source: Knowledge Assessment Methodology, 2018

The European Union has the second largest market in the creative economy, which is second only to the market of the Asia-Pacific region. Income from creative industries in European countries exceeds 700 billion dollars, that is, $32 \%$ of the world's creative sector income. Therefore, lately, there has been a strong interest taken by key EU and national governments in developing cultural and creative industries. Culture and the creative sector are recognized as sources of economic growth, dialogue in society and one of the key elements of the crisis in the EU (Global Economic Prospects, 2019). 
The EU renders significant state support to the creative economy, which manifests itself through the implementation of financial and tax privileges, purchasing activities, subsidies and promoting employment in the sector. So, creative companies occupied about $4.5 \%$ of the EU economy in 2017.

Over recent years, the contribution of creative and cultural industries to economic development has been characterized by a decline in all major industries, with the exception of broadcasting, the film industry, and information industries, mainly due to web development, software and programming (Table 9) (Beyers, et al. 2004). A special place was occupied by advertising activities in 2016, which during this period generated more than 143 billion dollars.

The Platform for Regional and National Developers for the Creative Industries Development Strategy and Business Support in this sector is the European Creative Industries Alliance (ECIA), founded in 2011. The Alliance's actions are aimed at supporting the operation of innovative vouchers, increasing financial support and developing clusters of advanced experience and cooperation in the creative and cultural industries (Vogel, 2001).

\section{Discussion}

The special value of the creative and cultural industries is that they are a powerful tool for improving the employment rate among young people. The proportion of people aged 15-29 was $19.1 \%$ of the total volume of creative activity in 2014. The Countries such as the United Kingdom and France are leaders in the number of young people in the creative sector. As a comparison, in Central and Eastern European countries, the tendency of proportional domination of the level of employment of young people in the creative and cultural industries is observed in comparison with other branches of economy.

Despite the innovation of creative industries, national economies, in particular the EU countries, play an active role in their development. Indices of the effectiveness of the functioning of creative industries in Europe clearly reflect their socio-economic impact: the economic efficiency of these industries brings income of \$ 709 billion dollars. and provides 7.7 million people with jobs

Today the European Union countries are working to overcome the communication barrier between the authorities and the public; the formation of a system of interaction between creative industries and other sectors of the economy, as well as on improving labor and tax policies for implementing business in the creative industries (Americans for the Arts, 2004). EU countries generate creative hubs that provide communication between cultural organizations and creative industries and conduct ongoing research in the field of culture (Ključnikov, et. al. 2019).

Europe is dominated by the 2017 list, with 11 of the 15 most competitive, creative economies on the continent. Switzerland, Denmark and Belgium remain the most competitive countries in the IMD World Talent 2017 ranking. Austria, Finland, the Netherlands, Norway, Germany, Sweden and Luxembourg make up the top ten (Table 10). IMD ratings as per 2017 confirm long-term trends in terms of talent competitiveness.

Denmark ranked second in the IMD World Talent rating. It is the first regarding the investment and development factor, in which it ranks fifth in the total public expenditure on education and public expenditure on education per student. The country is thriving in the process of implementing the educational process $\left(4^{\text {th }}\right.$ place $)$ and determining the priorities of training personnel $\left(2^{\text {nd }}\right.$ place). However, like in Switzerland, the quality of education in Denmark is relatively low for primary (13) and secondary (25) school. 
Table 10. Rating IMD World Talent, 2017

\begin{tabular}{|c|c|c|c|c|}
\hline Rating IMD & Country & Investments and development & Attractiveness & Wilingness \\
\hline 1 & Switzerland & 5 & 1 & 1 \\
\hline $\mathbf{2}$ & Denmark & $\mathbf{1}$ & 16 & $\mathbf{4}$ \\
\hline 3 & Belgium & 2 & 15 & 12 \\
\hline 4 & Austria & 3 & 24 & 5 \\
\hline 5 & Finland & 4 & $\mathbf{7}$ & $\mathbf{3}$ \\
\hline $\mathbf{6}$ & Netherlands & $\mathbf{1 5}$ & 13 & 14 \\
\hline 7 & Norway & 10 & 12 & 15 \\
\hline 8 & Germany & 9 & 4 & 19 \\
\hline 9 & Sweden & 16 & $\mathbf{1 9}$ & $\mathbf{2 0}$ \\
\hline 10 & Luxemburg & $\mathbf{3 7}$ & 62 & \\
\hline $\mathbf{2 1}$ & Great Britain & 35 & 60 \\
\hline
\end{tabular}

Source: Knowledge Assessment Methodology, 2018

The country is $10^{\text {th }}$ regarding the factor of attractiveness. In this respect, Denmark has high levels of employee motivation $\left(2^{\text {nd }}\right.$ place $)$, personal security and private property rights $\left(2^{\text {nd }}\right.$ place $)$, remuneration $\left(3^{\text {rd }}\right)$, and determining prioritization of attraction and retention of talent ( $3 \mathrm{rd}$ place). Although, such a result of attracting and retaining talent is used mainly for local employees, as Denmark ranks $25^{\text {th }}$ in terms of attractiveness for foreign highly skilled personnel. The country also has an extremely low index of the rate of personal income tax ( $63^{\text {rd }}$ place).

\section{Conclusions}

The methodology has been applied to determine the level of willingness of countries for the transition to a knowledge-based economy with a view to realize to what extent and which countries in the world are ready to transit to a knowledge-based economy, and thus have a well-developed, creative economy. The development of the main elements of knowledge-based economy in different countries of the world has been analyzed. Top ten countries have been allocated for each element of the knowledge-based economy.

According to the education index as an element of the knowledge-based economy, it has been discovered that, the most part of European and US countries have formed and continue developing a level of education that gives them the opportunity to transit to a knowledge-based economy, and hence to the development of a creative economy. According to the analysis of the index of innovations, which represents the ratio of costs and the effect, which allows to objectively evaluate the effectiveness of efforts made to develop innovation, have determined that European countries occupied higher positions, which again emphasized their desire and willingness to achieve a new economy. It has been discovered that Asian economies, such as China, Japan, Singapore, are gaining momentum in this part of the knowledge-based economy. This gives them a boost to a knowledgeable economy. Regional Leaders in Innovation have also been identified.

Considering the institutional regime for the knowledge-based economy has made it clear that there is a tendency to improve and develop this element in many countries. It has been found that the number of countries that use e-government to provide public services online through universal platforms has steeply risen; more and more countries are trying to ensure that public institutions to be more open, efficient, accountable and transparent with the help of e-government; many governments around the world open up their data to inform the public and to be under control; Thanks to easy access to social networks, an increasing number of countries are moving towards joint decision-making.

The state of the creative economy in the European countries was considered and the selected countries were evaluated regarding the development of their creative economy. Denmark performed the best, the worst results belonged to Great Britain. 


\section{References}

Americans for the Arts. (2004). Creative Industries Study. Washington, DC: Author. URL: https://www.arts.gov/sites/default/files/ Research-Art-Works-Milwaukee.pdf

Baltgailis, J. 2019. The issues of increasing the effectiveness of teaching comparative economics. Insights into Regional Development 1(3): 190-199. https://doi.org/10.9770/ird.2019.1.3(1)

Benešová, D., Hušek, M. (2019). Factors for efficient use of information and communication technologies influencing sustainable position of service enterprises in Slovakia, Entrepreneurship and Sustainability Issues 6(3): 1182-1194. http://doi.org/10.9770/jesi.2019.6.3(9)

Beyers, W., Bonds, A., Wenzl, A, \& Sommers, P. (2004). The Economic Impact of Seattle's Music Industry. Seattle: City of Seattle, Office of Economic Development. URL: https://www.seattle.gov/Documents/Departments/FilmAndMusic/Seattle_Music_EIS_2008.pdf

Center for an Urban Future, (2005). Creative New York. New York: Author. URL: https://nycfuture.org/pdf/Creative-New-York-2015.pdf

Dalevska, N., Khobta, V., Kwilinski, A., \& Kravchenko, S. (2019). A model for estimating social and economic indicators of sustainable development. Entrepreneurship and Sustainability Issues, 6(4), 1839-1860. https://doi.org/10.9770/jesi.2019.6.4(21)

Delery, J. E., \& Roumpi, D. (2017). Strategic human resource management, human capital and competitive advantage: is the field going in circles? Human Resource Management Journal, 27(1): 1-21. URL: https://onlinelibrary.wiley.com/doi/abs/10.1111/1748-8583.12137

Drobyazko S. (2019). Results of introduction of the improved mechanism of economic security control of insurance companies // International scientific journal "Internauka”. Series: "Economic Sciences”. — 2019. — №1. - 78 c. - C. 9-11. https://doi.org/10.25313/25202294-2019-1-4783

European Parliament resolution of on promoting the European cultural and creative sectors as sources of economic growth and job. Available on the Internet: http://www.europarl.europa.eu/sides/getDoc.do?type=REPORT\&reference=A7-2013-0248\&language=EN

Florida, Richard (2002). The Rise of the Creative Class, New York, Basic Books. https://doi.org/10.25071/1705-1436.180

Global Economic Prospects (2019). Available on the Internet: http://www.worldbank.org/en/publication/global-economic-prospects

Hall, P. (1998). Cities in civilization. New York: Pantheon Books

Howkins, John (2001). The Creative Economy. How people make money from ideas, The Penguin Press

IMD World Talent Ranking 2017. Available on the Internet: https://www.imd.org/wcc/world-competitiveness-center-rankings/talentrankings-2017/

Kiseláková, D., Šofranková, B., Čabinová, V., Onuferová, E. (2018). Competitiveness and sustainable growth analysis of the EU countries with the use of Global Indexes' methodology. Entrepreneurship and Sustainability Issues, 5(3), 581-599. http://doi.org/10.9770/ jesi.2018.5.3(13)

Knowledge Assessment Methodology (2018). The World Bank. Available on the Internet: http://worldbank.org/kam

Ključnikov, A., Popesko, B., Kloudová, J. (2019). Economics of the international ridesharing services - a trap for amateurs, Entrepreneurship and Sustainability Issues, 6(3): 1172-1181. http://doi.org/10.9770/jesi.2019.6.3(8)

Korauš, A., Dobrovič, J., Polák, J., Backa, S. (2019). Security aspects: protection of people in connection with the use of personal identification numbers, Journal of Security and Sustainability Issues 8(3): 319-330. http://doi.org/10.9770/jssi.2019.8.3(3)

Korauš, A., Mazák, M., Dobrovič, J. (2018). Quantitative analysis of the competitiveness of Benelux countries. Entrepreneurship and Sustainability Issues, 5(4), 1069-1083. http://doi.org/10.9770/jesi.2018.5.4(26)

Makedon, V., Drobyazko, S., Shevtsova, H., Maslosh, O., Kasatkina, M. (2019). Providing security for the development of hightechnology organizations, Journal of Security and Sustainability Issues 8(4): 1313-1331. http://doi.org/10.9770/jssi.2019.8.4(18)

Makedon, V., Hetman, O., Yemchuk, L., Paranytsia, N., Petrovska, S. (2019). Human resource management for secure and sustainable development, Journal of Security and Sustainability Issues 8(3): 345-354. http://doi.org/10.9770/jssi.2019.8.3(5)

Measuring the Information Society Report 2017. Available on the Internet: https:/www.itu.int/en/ITU-D/Statistics/Documents/ publications/misr2017/MISR2017_Volume1.pdf

OECD Science, Technology and Industry Scoreboard 2018. Available on the Internet: https://www.oecd.org/sti/scoreboard.htm

Prakash, R. Garg, P. (2019). Comparative assessment of HDI with Composite Development Index (CDI). Insights into Regional 
Development, 1(1), 58-76. https://doi.org/10.9770/ird.2019.1.1(5)

Ryan, P. (2003). The Creative Economy: Creative Clusters Key to Knowledge-based Economy, in "Marubeni Economic Report Tokio", Marubeni Corporation Economic Research Institute

Scott, A.J. (2003). The cultural economy of cities. London: Sage. http://dx.doi.org/10.4135/9781446247174.n29

Tepper, S. (2002). Creative assets and the changing economy. Journal of Arts Management, Law and Society, 32(2), 159-168. https://doi. org/10.1080/10632920209596971

The Global Innovation Index 2017. Available on the Internet: http://www.wipo.int/edocs/pubdocs/en/wipo_pub_gii_2017.pdf

Tkachenko, V., Kwilinski, A., Klymchuk, M., \& Tkachenko, I. (2019). The economic-mathematical development of buildings construction model optimization on the basis of digital economy. Management Systems in Production Engineering, 27(2), 119-123. http://doi. org/10.1515/mspe-2019-0020

Tvaronavičienė, M. (2018). Toward efficient policymaking: forecasts of vulnerability to external global threats, Journal of Security and Sustainability Issues 7(3): 591-600. https://doi.org/10.9770/jssi.2018.7.3(18)

UN E-Government Knowledge DataBase. Available on the Internet: https://publicadministration.un.org/egovkb/en-us/Data-Center

UNCTAD Creative Economy Outlook and Country Profile report (2018). Available on the Internet: https:/unctad.org/en/ PublicationsLibrary/ditcted2018d3_en.pdf

UNDP. Human Development Report (2018). Available on the Internet: http://hdr.undp.org/en/2018-update

Understanding the Engine of Creativity in a Creative Economy: An Interview with John Howkins. Available on the Internet: http://www. artsmanagement.net/index.php?module=News\&func=display \&sid=1057

United Nations e-government survey 2017. Available on the Internet: http://workspace.unpan.org/sites/Internet/Documents/UNPAN97453. pdf

Vogel, H. (2001). Entertainment industry economics. Revised ed. New York: Cambridge University Press.

World Intellectual Property Organization. Statistical Country Profiles. Available on the Internet: http://www.wipo.int/ipstats/en/statistics/ country_profile/profile.jsp?code=

Iryna PEREVOZOVA, Doctor of Economics, Professor, Head of the Department of Entrepreneurship and Marketing, Ivano-Frankivsk National Technical University of Oil and Gas

ORCID ID: orcid.org/0000-0002-3878-802X

Nadiia SHMYGOL, Doctor of Economic Sciences, Professor, Department of Accounting and Taxation, Zaporizhzhya National University

ORCID: ID: orcid.org/ 0000-0001-5932-6580

Dina TERESHCHENKO, PhD in Public Administration, Associate Professor of management and public administration Department, Associate Professor, Kharkiv National University of Civil Engineering and Architecture

ORCID ID: orcid.org/0000-0003-0633-0097

Kateryna KANDAHURA, Ph.D in State Administration, Associate Professor of the Department of Management, Kyiv National University of Trade and Economics

ORCID ID: orcid.org/0000-0003-4833-2234

Olga KATERNA, PhD (Economics), Associate Professor, Associate Professor National Aviation University ORCID ID: orcid.org/0000-0002-6307-8767

Register for an ORCID ID:

https://orcid.org/register

This work is licensed under the Creative Commons Attribution International License (CC BY).

http://creativecommons.org/licenses/by/4.0/ 